текстом і візуальну інформативність екрану. Передовий педагогічний досвід засвідчує, що кожне заняття з використанням Інтернет-сайтів викликає емоційний підйом.

Особливий інтерес нині викликають PowerPoint presentations, підготовка яких активізує пізнавальну діяльність студента, мотивує його до самостійного отримання знань та розвитку творчих здібностей.

Доцільно зазначити, що пошук сучасних методів та прийомів активізації пізнавальної діяльності майбутніх учителів у процесі вивчення іноземної мови нині $є$ однією 3 найважливіших методичних проблем. Використання методу дискусій, методу рольових ігор, методу проектів, мультимедійних технологій на заняттях з іноземної мови сприяє формуванню комунікативної компетенції студентів, розвитку окремих комунікативних, інтелектуальних, творчих здібностей, мотивує до плідної самостійної роботи, надає змогу керувати процесом засвоєння знань, активної участі в колективній та груповій роботі. Таке навчання у вищій педагогічній школі сприяє не тільки плідній роботі студента із засвоєння іноземної мови, а й формує педагога-професіонала, здатного до успішної передачі знань, умінь і навичок володіння мовою майбутнім учням.

\title{
Література
}

1. Виноградова О.С. Формирование иноязычной коммуникативной компетенции с использованием проблемных методов обучения ИЯ на продвинутом этапе специализированного вуза (на материале английского языка) : автореф. дис. на соискание ученой степени канд. пед. наук / О. С. Виноградова. - Москва, 2003. - 24 с. 2. Загальноєвропейські Рекомендації з мовної освіти : вивчення, викладання, оцінювання / наук. ред. укр. вид. С. Ю. Ніколаєва ; пер. $з$ англ. - К. : Ленвіт, 2003. - 273 с. 3. Конопляник Л. М. Активізація пізнавальної діяльності студентів майбутніх інженерів за допомогою новітніх педагогічних технологій / Л. М. Конопляник // Вісник НТУУ КПІ. Серія: Філософія. Психологія. Педагогіка. - К. : 2005. - Вип. 3 (15). - С. 65-69. 4. Морозова И. Г. Дискуссия как метод проблемного обучения и как средство формирования межкультурной компетенции на занятиях иностранного языка в вузах / И. Г. Морозова // Актуальные проблемы теории и методологии науки о языке. - Санкт-Петербург: ЛГУ им. А. С. Пушкина, 2010. - С. 41-51. 5. Національна доктрина розвитку освіти в Україні у XXI столітті // Освіта України. - 23 квітня 2002 р. - № 33. - С. 2-6.

УДК:370.181

Н. М. Гордій, кандидат. пед.наук, доцент, Глухівський начіональний педагогічний університет імені Олександра Довженка

\section{ВИКОРИСТАННЯ ДИТЯЧӦ̈ ЛІТЕРАТУРИ У ПРОЦЕСІ НАВЧАННЯ ПЕРЕКАЗУВАТИ ТЕКСТИ ДІТЕЙ ДОШКІЛЬНОГО ВІКУ}

Гордій Н. М. Використання дитячої літератури у процесі навчання переказувати тексти дітей дошкільного віку.

У статті розкрито питання розвитку зв'язного мовлення дітей дошкільного віку, обгрунтовано значущість використання літератури для дітей під час навчання переказувати, охарактеризовано показники рівнів розвитку зв'язного мовлення.

Ключові слова: зв'язне мовлення, література для дітей, переказування, мовленнєва компетенція.

Гордий Н. Н. Использование детской литературы в процессе обучения пересказу текстов детей дошкольного возраста.

В статье раскрыт вопрос развития связной речи детей дошкольного возраста, обоснованно значимость использования литературы для детей при обучении пересказывания, охарактеризованы показатели уровней развития речи.

Ключевые слова: связная речь, литература для детей, пересказывание, речевая компетенция.

Gordiy N. M. Using Children's Literature in the process of training retelling of preschool children. 
The article deals with the development of connected speech preschoolers, substantiates reasonable value of the use of literature for children with learning render, described performance levels of connected speech .

Key words: connected speech, literature for children transferring, linguistic competence.

Розвиток зв'язного мовлення дітей дошкільного віку є однією із стрижневих проблем дошкільної лінгводидактики. Ї̈і актуальність зумовлюється пріоритетними напрямами Національної доктрини розвитку освіти України у XXI столітті, Законів України «Про освіту», «Про дошкільну освіту», «Комплексними заходами щодо всебічного розвитку і функціонування української мови», спрямованими на модернізацію дошкільної освіти, оновлення змісту, вдосконалення форм, методів і технології навчання дітей рідної мови, розвитку культури мовлення та мовленнєвого спілкування.

Мовленнєве спілкування є одним із видів діяльності, яким дитина оволодіває в онтогенезі, воно $є$ універсальною умовою розвитку особистості в період дошкільного дитинства. Базова програма дошкільної освіти «Я у Світі» передбачає сформованість у випускника дошкільного закладу комунікативної компетенції. Мовленнєвий розвиток дитини є головним інструментом, за допомогою якого вона встановлює контакт із довкіллям і завдяки якому відбувається соціалізація дитини [1]. Водночас, як засвідчує практика, поширення комп'ютеризації, телебачення та інших технічних засобів, які стали доступними і дітям дошкільного віку, як у сім'ї, так і в дошкільних закладах, обмежують безпосереднє спілкування дітей 3 іншими мовцями, внаслідок чого збагачується пізнавальна сфера і водночас гальмується мовленнєва. Варто зазначити, що мовленнєва компетенція є однією з провідних базисних характеристик особистості, що формується на етапі дошкільного дитинства (А. Богуш, М. Вашуленко, Н. Гавриш, К. Крутій). Своєчасний та якісний розвиток зв'язного мовлення (діамонологічної компетенції) важлива умова повноцінного мовленнєвого розвитку випускника дошкільного навчального закладу.

Проблема розвитку зв'язного мовлення дошкільників не $\epsilon$ новою в науковій проблематиці. Вона досліджувалась класиками наукової думки і сучасними науковцями в різних аспектах: психологічному (Л. Виготський, Г. Леушина, О. Лурія, С. Рубінштейн), психолінгвістичному (І. Зимняя, О. Леонтьєв, О. Шахнарович), лінгвістичному (Т. Ладиженська, Л. Щерба), педагогічному (Л. Вороніна, В. Захарченко, С. Тихеєва), лінгводидактичному (О. Білан, А. Богуш, Н. Гавриш, Л. Фесенко). Досліджено такі аспекти зв'язного мовлення: навчання розповідання за дидактичними картинками (Н. Виноградова, Н. Гавриш, Л. Глухенька, Н. Смольнікова), переказування художніх творів (Р. Боша, О. Лещенко), навчання творчих розповідей (Н. Водолага, Н. Гавриш, С. Ласунова), розвиток зв'язного мовлення за текстами казок (С. Алієва, Л. Фесенко).

Науковці стверджують, що мовлення дитини є показником iї розумового розвитку. Особливої уваги потребує оволодіння усним монологічним мовленням - навчанням переказу, оскільки у процесі самостійного зв'язного висловлювання віддзеркалюється система набутих знань, уявлень і вражень, особливості становлення психічних процесів, а також рівень сформованості інших аспектів мовлення, звукової культури, граматичної будови, словника. Водночас практика засвідчує, що далеко не всі діти вміють послідовно, логічно висловлювати свої думки. У багатьох із них мовлення невиразне, уривчасте, 3 тривалими паузами, повторами через обмежений словниковий запас; вони невдало користуються мімікою, жестами, вдаються до слів-замінників і здебільшого мають труднощі у складанні розповіді.

Мета статmi - науково обгрунтувати й експериментально довести, що література для дітей $є$ важливим засобом у процесі навчання переказування дітей дошкільного віку.

Переказ - це свідоме відтворення літературного тексту в усному мовленні, складна діяльність, у якій беруть участь пам'ять, уява, мислення дитини [2]. Щоб переказувати, дитина має навчитися уважно слухати літературний текст, зрозуміти головний його зміст; запам'ятати послідовність епізодів сюжетної лінії і способи авторського передавання змісту; 
свідомо, зв'язно та виразно відтворити текст у процесі переказу. Роль переказів високо оцінювали корифеї педагогіки К. Ушинський та Л. Толстой, які вбачали в ньому обов'язкову умову опанування мовленнєвою діяльністю. Цієї ж думки дотримувалися й сучасні українські науковці О. Кононко, М. Стельмахович, які зазначають, що правильно організовані спостереження за зразками мовлення спонукають дитину до власної творчості [3]. Розрізняють такі види (способи) переказу: повний (цільний) переказ; переказ за частинами (командами); колективний переказ; інсценування за ролями; творчий переказ; вибірковий переказ [2].

Заняття 3 навчання переказу проводять на матеріалі добре знайомого дітям тексту (у молодшій та середній групах), а також незнайомого (у старшій групі). До переказу художніх творів висувається низка вимог: твір має бути доступним за змістом та обсягом; у творі мають чітко простежуватися частини: зачин, кульмінація і кінцівка; сюжет твору має розгортатися динамічно; короткі, чіткі фрази і речення; зміст твору має сприяти вихованню позитивних рис характеру, формуванню моральних якостей особистості [2].

Нами було проведено дослідження у ДНЗ № 1 «Чебурашка» м. Глухова, в експерименті взяли участь 20 дітей (10 - контрольної (КГ) і 10 - експериментальної (ЕГ) груп) віком 5-6 років. Констатувальний експеримент складався 3 декількох етапів. Спочатку було визначено рівень зв'язного мовлення дітей старшої групи, запропоновано різні питання 3 використанням сюжетних картинок (Наприклад: Кого зустрів Колобок у лісі? Опишіть героїв цієї казки). Було з'ясовано, наскільки діти обізнані з українськими народними казками. 3 дітьми експериментальних груп провели заняття з теми: «Чи знаєте ви казки та їх героїв?». Протягом тижня 3 дітьми експериментальної групи читали та обговорювали казки, вели спостереження, визначили, що діти частіше згадують казкових героїв, вигадують ігри та нові історії з ними. У полі посиленої уваги перебував не тільки рівень зв'язного мовлення дітей, але й набір частин мови. Щодо вживання лексем за частинами мови в розповідях дітей з'ясовано, що найчастіше вживалися іменники (58 \%), меншою мірою - дієслова (36\%), прислівники (15\%), прикметники (11\%), інші частини мови вживалися рідко.

У процесі дослідження було виявлено рівень зв'язного мовлення дітей контрольної групи. Графічні результати подано на рис. 1.

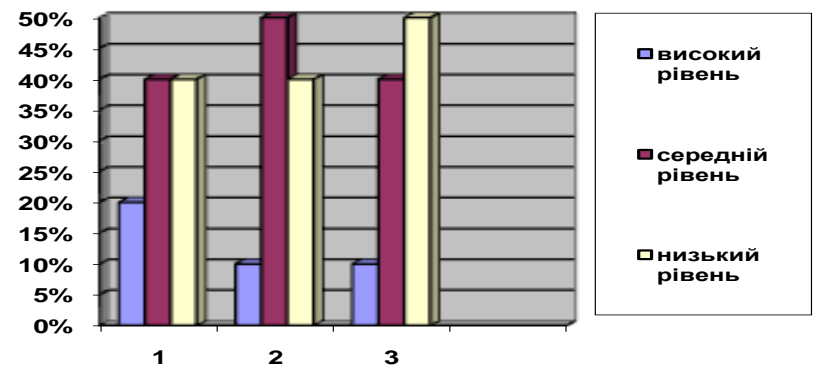

Рис. 1. Рівні зв'язного мовлення дітей ЕГ

Отже, як свідчать результати проведеного дослідження, діти КГ переважно мають середній та низький рівні зв'язного мовлення. У цих дошкільників динаміка зв'язного мовлення й набір частин мови потребує подальшого вдосконалення.

Рівень опанування зв’язного мовлення у дітей ЕГ і КГ подано на рис. 2. 


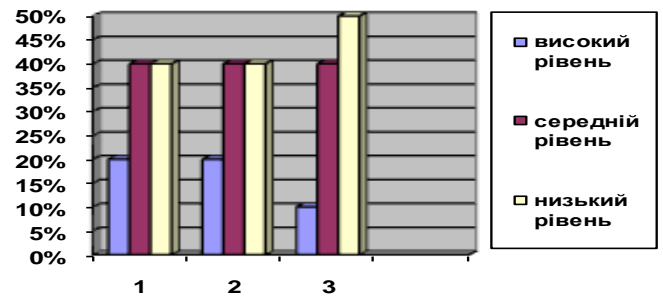

Рис. 2. Рівні зв’язного мовлення дітей КГ

На формувальному етапі експерименту завданнями дослідження стали з'ясування: рівня розвитку мовлення дітей у розповідях-переказах незнайомих текстів, характеру мовленнєвої активності дітей на занятті, коефіцієнта відтворення тексту. Для реалізації означених завдань було розроблено систему занять із художньої літератури 3 метою виявлення позитивних впливів на навчання переказування. Відповідно, було дібрано 5 казок різної складності: сюжети, що описані в розповідній формі, сюжети-діалоги з різною кількістю речень та слів. Твори були відібрані відповідно до вікових та індивідуальних особливостей дітей і Базової програми розвитку дитини «Я у Світі». Використовувались народні казки - «Пан Коцький», «Хитрий півень», «Брати-місяці», авторські - Л. Українки «Біда навчить», М. Трублаїні «Про дівчинку Наталочку та сріблясту рибку». У контрольних групах навчання дітей переказування проводилось за методикою, застосовуваною в сучасній практиці дошкільного виховання. В експериментальній групі навчання переказування відбувалось за допомогою різних способів моделювання, зокрема використовували: кольорову модель; модель за розміром; модель за формою.

Результати аналізу одних і тих же текстів казок дітей експериментальної та контрольної груп засвідчили їх суттєву відмінність за всіма показниками. Діти ЕГ не відчували труднощів у переказуванні текстів, вони не тільки правильно за сюжетом переказували зміст казок, але й виявляли творчість, добирали самостійно слова, переконструйовували фрази і речення, вдало використовували слова-замінники. Розповіді були послідовними, без пропусків і втручання педагогів, без пауз. Перекази дітей КГ мали стимульований характер, супроводжувалися паузами, в них були наявні пропуски сюжету, діти не вживали слів-замінників.

Дослідження використання способів переказу з метою розвитку зв'язного мовлення дітей 6-го року життя під час занять із художньої літератури було здійснено порівняльний аналіз результатів, отриманих у ході констатувального та контрольного етапів експерименту. Отримані результати дослідження рівня зв'язного мовлення дітей старшого дошкільного віку КГ та ЕГ було узагальнено та визначено загальний рівень зв'язного мовлення дітей 6-го року життя.

За результатами проведеного дослідження діти КГ і ЕГ мають такі рівні зв'язного мовлення (1 - контрольна група, 2 - експериментальна група).

Графічні зображення результатів подано на рис. 3 . 


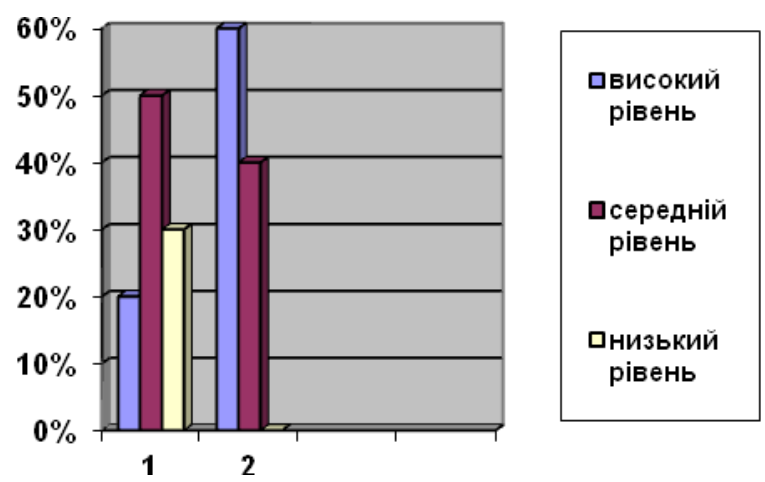

Рис. 3. Рівні сформованості зв’язного мовлення дітей контрольної та експериментальної груп

Проведене дослідження використання дитячої літератури у процесі навчання переказувати 3 дітьми 6-го року життя на заняттях із розвитку зв'язного мовлення за допомогою використання традиційної методики та різних способів моделювання виявлено позитивний результат проведеної роботи. Було зафіксовано позитивні зміни: рівень зв'язного мовлення дітей, показники обізнаності дітей дитячою літературою; набір частин мови у розповідях; показники відтворення тексту.

За результатами експерименту очевидним $\epsilon$ те, що навчання дітей старшого дошкільного віку переказувати за допомогою літератури буде ефективним за умови використання моделювання. Діти старшого дошкільного віку краще відтворюють текст твору, послідовно передають його зміст, використовують слова-замінники, що полегшує процес переказування твору. Вони 3 задоволенням виконували цю роботу, що задовольняло їхні емоційно-вольові запити.

Отже, використання дитячої літератури у процесі навчання переказувати твір із використанням способу моделювання $є$ ефективним засобом для розвитку зв'язного мовлення дітей старшого дошкільного віку.

\section{Література}

1. Базова програма розвитку дитини дошкільного віку «Я у Світі» / наук.кер. та заг.ред. О. Л. Кононко. - 3-тє вид.,випр. - К. : Світич, 2009. - 430 с. 2. Дошкільна лінгводидактика: Теорія і методика навчання дітей рідної мови: [підручник] / за ред. А. М. Богуш - К. : Вища шк., 2007. 542 c. 3. Зав'язун Т. В. Нетрадиційні методи роботи з казкою як засіб розвитку мовленнєвокомунікативних здібностей старших дошкільників / Т. В. Зав’язун, О. В. Семенюк // Обдарована дитина. - 2008. - № 9. - С. 41-48.

\section{ДИДАКТИЧНІ ОСОБЛИВОСТІ ПОБУДОВИ ЕФЕКТИВНОЇ ОРГАНІЗАЦІЇ КОНТРОЛЮ МАТЕМАТИЧНОЇ ПІДГОТОВКИ МАЙБУТНІХ ЕКОНОМІСТІВ}

Грибонос Є. Ю. Дидактичні особливості побудови ефективної організації контролю математичної підготовки майбутніх економістів.

У статті наголошено на необхідності розробки ефективної організації контролю навчальних досягнень майбутніх економістів у процесі вивчення математичних дисциплін на основі виявлених у сучасній практиці суперечностей та інновацій у сфері освіти. Розкриті дидактичні особливості побудови ефективної організації контролю математичної підготовки майбутніх економістів.

Ключові слова: майбутній економіст, організація контролю навчальних досягнень, математичні дисципліни. 